\title{
MALAYSIAN INDIVIDUAL INVESTORS: WHAT ARE THE FACTORS THAT INFLUENCE THEIR FINANCIAL STATEMENT USAGE?
}

\author{
K. Kishan* and Ervina Alfan
}

\begin{abstract}
Research aim: This study seeks to examine the knowledge and attitudinal factors that influence financial statement usage among Malaysian individual investors.
\end{abstract}

Design/ Methodology/Approach: A survey was conducted on a sample of 399 Malaysian individual investors using self-administered questionnaires.

Research finding: The findings reveal that financial statement usage is positively associated with subjective norm, financial statement knowledge, attitude towards financial statement usage, and perceived behavioural control. However, it is negatively associated with trading frequency attitude.

Theoretical contribution/Originality: This study seeks to contribute to the very limited research on the factors that influence individual investors' financial statement usage. Additionally, it enriches the literature on financial statement usage among individual investors in Malaysia by showing the extent to which the three main financial statements are utilised by them. Furthermore, this research extends financial literacy research on stock investing to the realm of financial statement usage by highlighting the influence of financial statement knowledge on this behaviour. Thus, the study seeks to bridge the gap between financial reporting and financial literacy.

Practitioner/Policy implication: The findings provide useful insights for the providers of investor education programmes in developing more holistic programmes.

Research limitation/Implication: Non-random sampling was employed in this study, albeit such an approach is consistent with the literature. Also, respondents comprised individual investors who are proficient in English because the researchers seek to complement Malaysian studies on the readability of English language financial statement narratives.

Keywords: Financial Reporting, Investment Decision-making, Financial Knowledge

Type of manuscript: Research paper

JEL Classification: M41, G41, D80

*Corresponding Author: K. Kishan, is a PhD scholar in the Department of Accounting, Faculty of Business and Accountancy, University of Malaya 50603 Kuala Lumpur, Malaysia; a Certified Financial Planner (CFP) and a member of the Malaysian Association of Company Secretaries (MACS). Email: kishan_krishnen@yahoo.com

Ervina Alfan, PhD is a Senior Lecturer in the Faculty of Business and Accountancy, University of Malaya, 50603 Kuala Lumpur, Malaysia. Email: ervina_alfan@um.edu.my 


\section{Introduction}

Financial statements are prepared by companies to provide useful information for stock investment decision-making. However, financial statement usage by individual investors is not widespread. While intended for general investors, the paradox of financial statements is that only users with sufficient accounting knowledge and skills would be able to understand and use them effectively for investment decision-making purposes. Such a conundrum is problematic for individual investors who are generally regarded as less sophisticated and informed than institutional investors (Barber \& Odean, 2008). Indeed, individuals lack the professional expertise, time, and other resources possessed by institutional investors when searching and analysing information (Miller, 2010), thereby compounding the issue of the growing financial statement complexity (ACCA, 2012; KPMG, 2011), which places tremendous demands on users and is tantamount to information overload for nonprofessional individual investors.

Stock investing is popular among Malaysians owing to the relative simplicity of becoming an investor. The only requirement is that one must be 18 years old and above to open a Central Depository System (CDS) account, which is a mandatory requirement of Bursa Malaysia (2016). In 2016, there were 2.49 million CDS account holders in Malaysia (Aruna, 2017) and the country has the second highest population of individual investors per capita in Southeast Asia (Hermanus, 2015). Hence, the study of individual investors in Malaysia merits closer attention owing to their significance in terms of numbers.

Interestingly, despite being in an apparently disadvantageous position, researchers report that Malaysian individual investors are largely rational decision-makers who rely on financial statements analysis (Jamal, Ramlan, Pazim, \& Budin, 2014; Lai, Low, \& Lai, 2001; Lai, Tan \& Chong, 2013; Nik Muhammad \& Abdullah, 2009). This suggests that their financial statement usage is high, albeit another study suggests the contrary (Jaiyeoba \& Haron, 2016). Therefore, in view of these conflicting findings, it is worth examining what motivates Malaysian individual investors to rely on financial statements when making stock investment decisions.

The objective of this study is to examine knowledge and attitudinal factors that influence financial statement usage among individual investors in Malaysia. Specifically, it investigates the extent to which the following factors are associated with financial statement usage: financial statement knowledge, trading frequency attitude, financial statement usage attitude, subjective norm, and perceived behavioural control. 
These variables were derived from the underlying theories used in this study and were selected based on inferences made from the literature. While there is a wealth of research on the usefulness of financial statements, examining factors that influence individual investors to use financial statements for investment decision-making remains largely under-researched. Hence, this study seeks to contribute to this nascent field of study.

The rest of the paper is organised as follows. In Section 2, we review the relevant literature and develop our hypotheses. Section 3 describes the research methodology, while Section 4 presents the findings and discussion. Section 5 concludes.

\section{Literature Review and Hypotheses Development}

This section reviews prior studies that are relevant to this research. The theoretical framework and hypotheses development are then described.

\subsection{Usefulness of Financial Statements}

The usefulness of financial statements as sources of information for stock investment decision-making purposes is underscored in international accounting standards as well as national legislations. For example, Paragraph OB2 of the Malaysian Accounting Standards Board Conceptual Framework (Malaysian Accounting Standards Board, 2011) states:

The objective of general purpose financial reporting is to provide financial information about the reporting entity that is useful to existing and potential investors, lenders and other creditors in making decisions about providing resources to the entity. Those decisions involve buying, selling or holding equity and debt instruments, and providing or settling loans and other forms of credit. [Emphasis added]

Similarly, Subsection 248 (1)(b) of the Companies Act 2016 of Malaysia stipulates that listed companies are required to prepare their financial statements within six months of their financial year end.

The accounting information in financial statements is value relevant, meaning that it can be used to estimate the intrinsic or fundamental value of a company. Fundamental analysis can be defined as "a practice that relies heavily on the analysis of current and past financial statement data to identify when underlying firm value differs from prevailing market prices" (Abarbanell \& Bushee, 1998, p. 20). The principle underlying fundamental analysis is that the intrinsic value of a security 
equals the discounted values of its expected future cash flows (Richardson, Sloan, \& You, 2012). Fundamental analysis is part of a broader investment strategy known as value investing, which involves investing in undervalued stocks (Graham \& Dodd, 2009; Graham \& Zweig, 2006). Value investing has been proven to generate superior returns for investors (Piotroski, 2000).

By analysing accounting information using mathematical formulae, some scholars provide empirical support of the value relevance of financial statements (Brimble \& Hodgson, 2007; Francis \& Schipper, 1999). However, others assert that financial statements are less value relevant (Dontoh, Radhakrishnan, \& Ronen, 2004).

Financial statement usage among investors has been the subject of some studies. According to Nagy and Obenberger (1994), investors rank financial statements as very important sources of information for investment decision-making. Several studies support these findings (AlAjmi, 2009; De Zoysa \& Rudkin, 2010; Drake, Roulstone, \& Thornock, 2016; Johansen \& Plenborg, 2013).

\subsection{Numerical Accounting Information in Financial Statements}

Financial statements comprise three main elements, which are prose (narratives), images (graphs, charts, and pictures), and quantitative (numerical accounting information). There is extensive research on financial statement prose with researchers focusing on the readability of narratives to assess the understandability of prose. In short, researchers in English-speaking countries found that such narratives ranged from difficult to very difficult to read (Brennan, Pierce, \& Guillamon-Saorin, 2009; Jones \& Shoemaker, 1994). Research in Malaysia has yielded similar findings (Abdul Raman, Mohd Shaari, \& Mahmud, 2012; Mohammad \& Abdul Rahman, 2006). The readability of narratives impacts investors because research shows that small investors are deterred from investing in firms with low financial statement readability (Miller, 2010). Additionally, low readability is sometimes linked to obfuscation and deceptive management practices (Hrasky, Mason, \& Wills, 2009; Loughran \& McDonald, 2014). Researchers also found that images are generally used for impression management strategies (Beattie, Dhanani, \& Jones, 2008; Stanton \& Stanton, 2002).

Despite the importance of the numerical accounting information in financial statements, less research is devoted to the understandability of the information to individual investors. While some researchers provide evidence that financial statements are used by investors (Drake et al., 2016; Johansen \& Plenborg, 2013), others examine the accounting 
information cues that are used for decision-making (Libby, 1975) and how this information is interpreted by users (Libby, Bloomfield, \& Nelson, 2002). A few also investigate the influence of accounting information in financial statements on stock prices (Chen \& Zhang, 2007). The apparent lack of research on the understandability of the numerical accounting information in financial statements is regrettable because narratives, such as notes to the financial statements, can only be effectively understood if the reader is able to understand the numerical information in the income statement, balance sheet, and cash flow statement.

Yet, unlike research on narratives, there are few major studies on how well investors understand the accounting information in financial statements. This issue is pertinent due to the growing financial statement complexity owing to changes in the international financial reporting regime. Assessing how well investors understand financial statements requires evaluating their knowledge of financial statements, which is related to the field of research on financial literacy.

\subsection{Financial Literacy}

Financial literacy is a concept that has so far eluded a universal definition. Several researchers define it within the confines of financial knowledge and skills (Abreu \& Mendes, 2010; Arora \& Marwaha, 2013; Hung, Parker, \& Yoong, 2009). Huston (2010) asserts that financial literacy should encompass both the knowledge and application dimensions. In this regard, it is useful to review the definition of financial literacy by the Organisation for Economic Co-operation and Development (OECD), which has conducted numerous surveys over the years to assess the international levels of financial literacy. Apart from that, via its International Network on Financial Education (OECD/INFE), this international body is a strong advocate of the importance of financial education for elevating the financial condition of various segments of society. The OECD defines financial literacy as "a combination of awareness, knowledge, skill, attitude and behaviour necessary to make sound financial decisions and ultimately achieve individual financial wellbeing" (Atkinson \& Messy, 2012, p. 14).

The importance of financial literacy in various stages of our life-cycle is well-documented. For instance, college students with low financial literacy have a greater probability of having money management problems and inadequate savings (Ibrahim, Harun, \& Isa, 2009; Sabri \& McDonald, 2010). Adults with low financial literacy are shown to have lower emergency savings (Babiarz \& Robb, 2014), lack personal financial 
planning (Hung et al., 2009), and are less prepared for retirement (Alessie, van Rooij, \& Lusardi, 2011). On the other hand, adults with high financial literacy are more likely to participate in a retirement plan (Howlett, Kees, \& Kemp, 2008), have more savings (Landerretche \& Martinez, 2013), earn higher returns on their retirement savings plan (Clark, Lusardi, \& Mitchell, 2014), and have greater household wealth (Behrman, Mitchell, Soo, \& Bravo, 2012; Jappelli \& Padula, 2011). Low financial literacy among senior citizens has serious ramifications for their economic well-being (Lusardi \& Mitchell, 2011; Lusardi, Mitchell, \& Curto, 2014).

Numerous studies are of the consensus that, on average, global financial literacy levels are low (Klapper, Lusardi, \& van Oudheusen, 2015; OECD/INFE, 2016; Xu \& Zia, 2012). Even though developed countries report higher levels of financial literacy, wide disparities exist in terms of gender, age, ethnicity, region, and income. As for the developing world, the financial statement literacy rates are generally low. This poses serious problems for economic growth and development, especially since low financial literacy is associated with financial exclusion. Indeed, people need high levels of financial literacy to comprehend increasingly complex financial products and services.

Financial literacy in the context of stock investing has been a focus of some research. Several studies show that stock market participation (or the lack thereof) is influenced by financial literacy (van Rooij, Lusardi, \& Alessie, 2007; Xia, Wang, \& Li, 2014; Yao \& Xu, 2015). Researchers also found that financial literacy influences portfolio diversification (Abreu \& Mendes, 2010; Mouna \& Jarboui, 2015) and financial risk taking (Wang, 2009).

Reading and understanding financial statements require a specific type of knowledge, which we term financial statement knowledge. This refers to knowledge of the key terms and concepts used in the financial statements. One of the few studies on the subject is by Callen, Lai and Wei (2016) who examined the influence of financial statement knowledge (described as financial statement literacy) and its effect on earnings revisions by individual investors. However, this paper relies on secondary data and does not evaluate the level of financial knowledge of the users.

In summary, while there is a wealth of research on the users of financial statements, the types of information they rely on, and the benefits of financial statements usage, it is still unclear what influences some investors to rely on financial statements for investment decisionmaking while others do not. This represents a gap that this article seeks 
to address. Nonetheless, insights from the literature reveal that financial knowledge and attitudes influence financial behaviour. Therefore, further investigation is needed to examine the influence of financial statement knowledge and attitudinal factors on individual investors' financial statement usage for investment decision-making. The next subsection describes the theoretical framework.

\subsection{Theoretical Framework}

The theoretical framework of this study combines human capital theory and the theory of planned behaviour (TPB). While human capital theory has long been used to explain the relationship between education and labour productivity (Psacharopoulos, 2006), its application has been extended to other fields including financial literacy. Lusardi and Mitchell (2014) state that financial knowledge is a form of human capital investment that contributes to greater wealth and prosperity. Several financial literacy studies that explain the relationship between financial knowledge and financial behaviour are underpinned by human capital theory (such as Delavande, Rohwedder, \& Willis, 2008; Helppie, Kapinos, \& Willis, 2010; Jappelli \& Padula, 2011; Monticone, 2010, Spataro \& Corsini, 2013). In this study, financial statement knowledge is regarded as a type of human capital that increases individual investors' financial statement usage for investment decision-making, which, in turn, contributes to superior investment decisions and wealth maximisation. Hence, it is postulated that financial statement knowledge is associated with the usage of financial statements for investment decision-making among individual investors. However, the literature on financial literacy also suggests the influence of financial attitudes on financial behaviour (for example, Atkinson \& Messy, 2012).

Therefore, TPB, as developed by Ajzen (1991), is selected to explain the influence of attitudinal factors on the usage of financial statements for investment decision-making among individual investors. TBP states that actual behaviour is preceded by a person's intention to perform that behaviour. Behavioural intention is influenced by three factors; namely, attitude towards the behaviour, subjective norm, and perceived behavioural control. In a similar vein, it is postulated that trading frequency attitude, attitude towards financial statement usage, subjective norm, and perceived behavioural control would influence financial statement usage by individual investors. Previously, several studies employed TPB to explain factors that influence stock market participation by individual investors (Pascual-Ezama, Scandroglio, \& Liaño, 2013; Phan \& Zhou, 2014; Sondari \& Sudarsono, 2015). 
This study adopts a streamlined TPB model in which the construct on behavioural intention is omitted. There are several precedents for the omission of this construct in studies that examine the direct relationships between the TPB predictor variables and actual behaviour (Dennis, Buchholtz, \& Butts, 2009; Moser, 2015; Warner \& Aberg, 2006). The hypotheses development is discussed next.

\subsection{Hypotheses Development}

This section discusses the various hypotheses developed to fulfil the research objectives.

\subsubsection{Financial Statement Knowledge}

Many studies indicate that financial knowledge is positively correlated with positive financial behaviour (such as Asaad, 2015; Atkinson \& Messy, 2012; Babiarz \& Robb, 2014; Robb, 2011). However, others report little or no correlation between these two variables (Loke, 2015; Robb \& Woodyard, 2011). We postulate that investors with high financial statement knowledge would extensively use financial statements when making stock investment decisions, although it is also possible that such knowledge would not translate into the desired behaviour. Hypothesis 1 is as follows:

$\mathrm{H}_{1}$ : Financial statement knowledge is positively associated with individual investors' financial statement usage for investment decision-making.

\subsubsection{Trading Frequency Attitude}

Studies show that individual investors tend to trade too often (Barber, Lee, Liu, \& Odean, 2009; Barber \& Odean, 2013). Such tendencies perhaps emerge from the fallacious belief that one must trade frequently to make a profit even though research shows that traders consistently underperform benchmarks (Barber \& Odean, 2000; Linnainmaa, 2011). Yet, many cannot resist the temptation of active trading. Trading frequency increases when investors are overconfident about their ability (Graham, Harvey, \& Huang, 2009; Grinblatt \& Keloharju, 2009; Statman, Thorley, \& Vorkink, 2006). Trading frequency may impact the usage of financial statements by individual investors. Since trading is driven by short-term price fluctuations and other signals, it is possible that investors who trade frequently are less inclined to rely on financial statements when making stock investment decisions:

$\mathrm{H}_{2}$ : Trading frequency attitude is negatively associated with individual investors' financial statement usage for investment decision-making. 


\subsubsection{Financial Statement Usage Attitude}

Research in other countries demonstrates that individual investors regard financial statements as important sources of information about a company's performance (Al-Ajmi, 2009; De Zoysa \& Rudkin, 2010). In Malaysia, the situation is less clear owing to a lack of published studies on the subject. However, prior research shows that investors are reliant on financial statement analysis (Jamal et al., 2014; Nik Muhammad \& Abdullah, 2009), which implies the usage of financial statements. Since TPB indicates that attitude towards behaviour is correlated with the behaviour itself, we hypothesise the following:

$\mathrm{H}_{3}$ : Financial statement usage attitude is positively associated with individual investors' financial statement usage for investment decision-making.

\subsubsection{Subjective Norm}

According to TPB, subjective norm influences our behaviour. Subjective norm can be defined as the influence of family, friends, and other influential people (Carpenter \& Reimers, 2005). Subjective norm can exert a powerful social pressure on our financial behaviour (Agarwalla, Barua, Jacob, \& Varma, 2013; Chung \& Park, 2014; Ibrahim et al., 2009; Robb, 2011; Sabri \& McDonald, 2010). It is possible that the likelihood of individual investors using financial statements for investment decisionmaking increases when they feel that people who are influential to them as investors use financial statements and expect them to do so. Hence, we postulate the following:

$\mathrm{H}_{4}$ : Subjective norm is positively associated with individual investors' financial statement usage for investment decision-making.

\subsubsection{Perceived Behavioural Control}

Ramayah, Yusoff, Jamaludin and Ibrahim (2009, p. 274) state that "when purchasing an innovative product, consumers may not only need more resources (time, information, etc.) but also more self-confidence in making a proper decision." The same principle applies when investing in equities, which are complex financial products. Indeed, investors display greater confidence when they feel they are in control of their investment decisions (Wood \& Zaichkowsky, 2004). Perceived behavioural control is demonstrated to influence behaviour, as per TPB. In this paper, perceived behavioural control refers to the perceived difficulty (or ease) of understanding financial statements. We hypothesise that individual investors with greater confidence in their ability to understand financial statements are more likely to use them when investing: 
What Are the Factors That Influence Their Financial Statement Usage?

$H_{5}$ : Perceived behavioural control is positively associated with individual investors' financial statement usage for investment decision-making.

The research model for this study is represented diagrammatically in Figure 1.

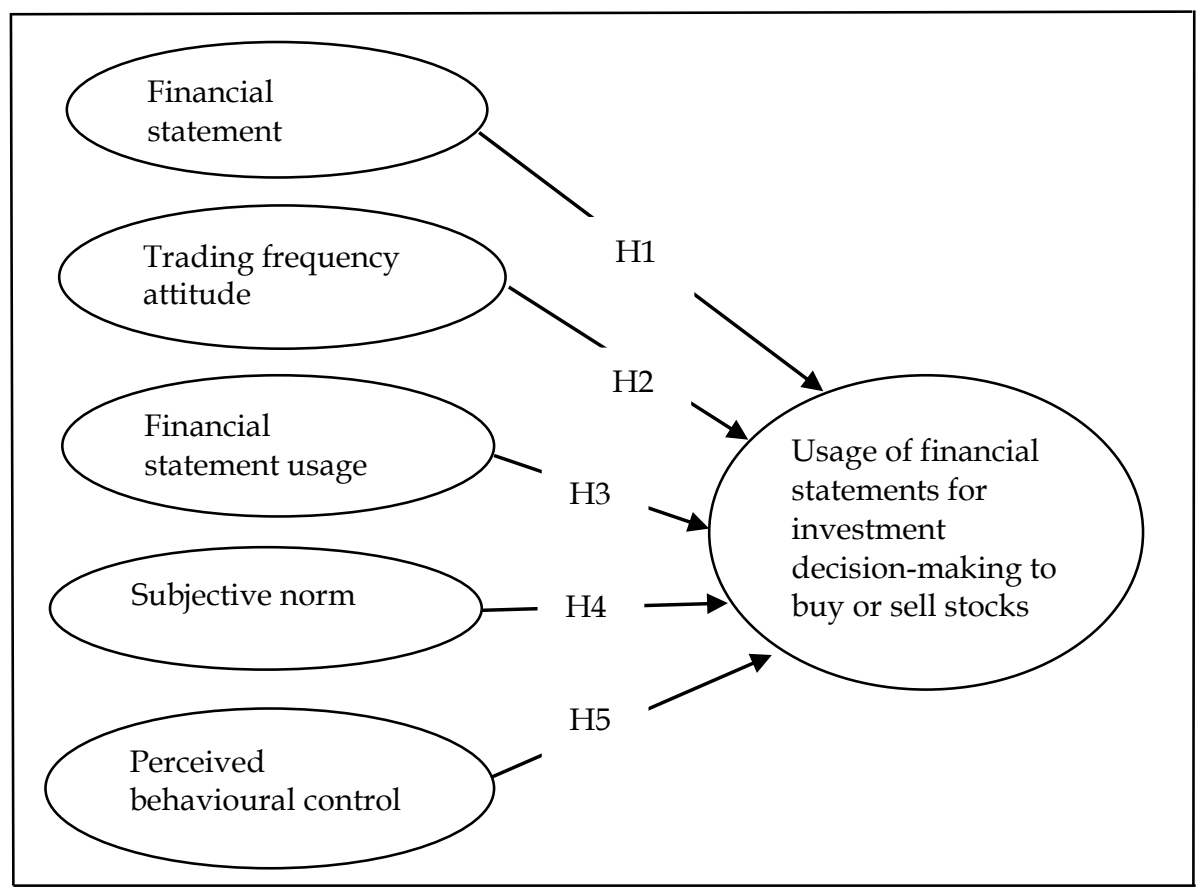

Figure 1. Research model

\section{Methodology}

The methodology of this research is described here beginning with how the variables are operationalised followed by discussions on the research instrument, sampling method, data collection method and data analysis procedure.

\subsection{Operationalising Variables}

These are discussed as follows.

\subsubsection{Financial Statement Knowledge}

We define this variable as the respondent's actual knowledge level of terms and concepts in financial statements as well as the ability to calculate financial ratios. These financial statements are the balance sheet 
(statement of financial position), income statement, and cash flow statement. While there are other financial statements, such as the statement of changes in equity, the literature and our expert panel feedback indicate that the three abovementioned financial statements are the most relevant for financial statement analysis. This variable assesses the objective financial statement knowledge of individual investors, which is the actual knowledge of the respondents. Objective financial knowledge is a more reliable measure compared to subjective or selfperceived financial knowledge (Hung et al., 2009). The variable is measured using eight multiple choice questions with four options each. These questions assess the knowledge of the income statement, balance sheet, and cash flow statement. For example, one question asks what a balance sheet is. Consistent with Lusardi and Mitchell (2011), included is the option for "Do not know". The correct answers for each question are totalled to arrive at a final score for the financial statement knowledge of the respondent.

\subsubsection{Trading Frequency Attitude}

This is defined as the investors' attitude regarding how frequently they need to trade to make a profit on a stock, and captures whether the individual has investor or gambler traits. The list of items for this variable are adapted from the instrument by Lease, Lewellen and Schlarbaum (1974), and suggestions by the expert panel. For instance, one item states "The more often I trade in stocks, the better my chances of making a profit on my investment." All three items are measured using a 7-point Likert scale ranging from strongly disagree (1) to strongly agree (7).

\subsubsection{Financial Statement Usage Attitude}

This is defined as the extent to which the individual investor perceives that using financial statements in the annual report is as important in making investment decisions to buy or sell stocks. This variable is measured through three items using a 7-point Likert scale. An example of these items is "Financial statements in annual reports are important sources of information about the performance of companies" and ranges from strongly disagree (1) to strongly agree (7). Items are derived from the guidelines set in TPB (Ajzen, 2006, 2011) as well as the preliminary field interviews with investors and expert panel validation. 


\subsubsection{Subjective Norm}

The subjective norm is defined as the extent to which the individual investor believes others who are significant to him or her as investors use annual report financial statements for investment decision-making to buy or sell stocks, and expect him or her to do likewise. To measure the subjective norm, Ajzen (2006) recommends including questions that can capture descriptive norms, meaning whether the behaviour in question is performed by significant others. In addition, questions with an injunctive quality can be asked to add variability to the structure of questions. A 7point Likert scale is used to measure the four items for this construct. One such item reads "Most people like me regularly use financial statements in annual reports to help them make investment decisions to buy or sell stocks;" the response ranges from strongly disagree (1) to strongly agree (7).

\subsubsection{Perceived Behavioural Control}

Perceived behavioural control is defined in the context of the study as the perceived difficulty (or ease) of reading and understanding annual report financial statements for individual investors. This is based on the investors' level of self-confidence in using financial statements, which, in turn, is influenced by their subjective annual report financial statement knowledge. The four items for this variable are measured using a 7-point Likert scale. An example of these items is "I find financial statements in annual reports easy to understand;" the response ranges from strongly disagree (1) to strongly agree (7).

\subsubsection{Financial Statement Usage for Investment Decision-Making}

The dependent variable is usage of financial statements for investment decision-making to buy or sell stocks. It is operationalised as how often in the past 12 months the individual investor has used the three financial statements in annual reports as sources of information when making a decision whether to buy or sell stocks. Although companies publish other financial statements, such as quarterly reports, annual report financial statements are selected as proxies for financial statement usage because they are the most comprehensive financial statements issued by companies on a regular basis. The three items - the income statement, balance sheet, and cash flow statement - for this variable examine how often in the past 12 months the investor has used the following financial statements in annual reports to help them make a decision on whether to buy or sell a stock. The variable is measured using a 7-point Likert scale 
for each item ranging from never (1) to always (7). Once again, the items are derived from the guidelines set in the theory of planned behaviour (Ajzen, 2006, 2011) as well as the preliminary field interviews with investors and expert panel validation.

\subsection{Research Instrument}

The research instrument is a printed self-administered questionnaire in English. A preliminary list of items was generated from the literature and field interviews with ten individual investors who have at least seven years of experience. These investors provided face validity for the items. In addition, the preliminary list of financial knowledge questions was tested on 64 business diploma students to ascertain the level of difficulty. The preliminary list of items and their measures was then sent for review by an expert panel of six members for content validation.

A pilot study involving 40 individual investors was then conducted. These comprised participants of an earlier investor education seminar conducted by the same stock brokerage firm that assisted in the research study. The responses from eight investors were discarded as they contained one or more incomplete items, leaving a total of 32 usable questionnaires. The reliability of the pilot questionnaire was assessed using Cronbach's alpha and corrected item-total correlations.

\subsection{Sampling Method}

The population for this study comprises Malaysian individual investors transacting on Bursa Malaysia. The sampling frame consists of all the individuals with a CDS account, which is approximately 2.49 million people (Aruna, 2017). The unit of analysis for this study is individual investors between the ages of 21 and 60. Studies demonstrate that financial literacy declines after the age of 60 (Xu \& Zia, 2012), so this age range was selected to assess the financial statement knowledge and behaviour of working adults. Using the table by Fowler (2009), a margin of error of 5 per cent and 95 per cent confidence level, the required sample size for this study is 384 respondents.

While random sampling is acknowledged as superior to non-random sampling (Creswell, 2014), many studies on individual investors in Malaysia employ non-random sampling methods (for instance, Jamal et al., 2014; Lai et al., 2013; Tan, Hoe, \& Hung, 2011) owing to the population size and dispersion of members. Furthermore, the Personal Data Protection Act 2010 has placed further restrictions by prohibiting intermediaries, such as stockbrokerage firms, from disclosing the contact 
details of individual investors. Hence, we employed a purposive sampling approach.

\subsection{Data Collection Method}

We enlisted the help of a large stock brokerage firm to distribute the questionnaires to their clients who attended investor education seminars that the firm conducts regularly at weekends. The respondents comprised the participants of seminars at the firm's headquarters in Kuala Lumpur, as well as its branches in Johor Bahru and Penang. The data collection method shares similarities with Khan, Tan and Chong (2016) as well as Ali, Rahman and Bakar (2015). The reliance on data from a single stockbrokerage firm is consistent with the literature (for example, Barber \& Odean, 2000; Ben-David \& Hirshleifer, 2012; Kumar, 2009).

Respondents were requested to answer the questionnaire during a 30-minute seminar break. This data collection method was chosen for three main reasons. One, since we were unable to directly contact individual investors, the stockbrokerage firm acted as an intermediary between us and the target respondents. Two, it was selected to minimise the possibility of respondents "cheating" on the financial statement knowledge questions. Financial statement analysis was not one of the topics discussed during these seminars. Hence, the answers provided by respondents for the multiple-choice questions reflect their actual financial statement knowledge and not what they learned during the seminar. The respondents were required to answer the questionnaire during a fixed period of 30 minutes, so there was less time and opportunity for them to read up the answers to the financial knowledge questions; the likelihood of which would be higher for a take-home, mailed, or online questionnaire. Furthermore, since the participants were generally complete strangers to one another, the probability of individuals sharing and discussing answers was reduced. Three, this approach allowed us to obtain a sufficiently large sample with a high response rate in a relatively short time, and at lower cost.

\subsection{Data Analysis}

Preliminary data analysis consisted of tabulating the means, standard deviations, and correlations among the variables. To examine the demographic differences among the financial statement usage, a t-test was done for gender while analysis of variance (ANOVA) was conducted for the remaining five demographic variables. Multiple regression 
analysis was performed as it has been employed in previous financial literacy (Atkinson \& Messy, 2012; Sabri \& Macdonald, 2010) and TPB studies (Ajzen, Joyce, Sheikh, \& Cote, 2011; Dennis et al., 2009; Gopi \& Ramayah, 2007). The regression model for this study is as follows:

$$
\operatorname{TotB}_{i}=\beta_{0}+\beta_{1} \operatorname{TotFSK}_{i}-\beta_{2} \operatorname{TotF}_{i}+\beta_{3} \operatorname{Tot}_{i}+\beta_{4} \operatorname{Tot}_{i}+\beta_{5} \operatorname{TotPCB}_{i}+\varepsilon_{i}
$$

where

$T_{0} t B_{i}$ represents individual investors' financial statement usage for investment decision-making.

TotFSK $_{i}$ represents financial statement knowledge.

Tot $F_{i}$ represents trading frequency attitude.

$T_{0} t U_{i t}$ represents financial statement usage attitude.

Tot $S_{i}$ represents the subjective norm.

$T o t P C B_{i}$ represents perceived behavioural control.

$\varepsilon_{i}$ is the error term.

\section{Results and Discussion}

This section presents the key findings followed by the discussion.

\subsection{Data Collection Results}

Data collection commenced in August 2016 and was completed in November 2016. Out of 423 seminar participants, we received a total of 414 responses. However, 15 contained one or more incomplete answers and were duly discarded. We were left with 399 usable questionnaires, which met our minimum required sample size of 384 . Since the response rate was 94.3 per cent, the non-response bias was minimised. The profile of the respondents is discussed next.

\subsection{Profile of Respondents}

The majority of the respondents were male, which is consistent with prior studies (Jamal et al., 2014; Khan et al., 2016, Lai et al., 2013, Nik Muhammad \& Abdullah, 2009). Similar to the racial composition in the research by Yeoh (2010), Chinese comprised the largest ethnic group, followed by Malays, Indians, and others. Many of the respondents were young, being in their 20s and 30s. Almost 80 per cent of the respondents possessed a post-secondary school education. The figure was notably higher than the national average of 16.37 per cent (Ministry of Education Malaysia, 2016) and suggestive of the relationship between educational attainment and stock ownership (van Rooij et al., 2007). The vast majority 
were private sector employees. Many had stock investing experience of three years or less. A summary of the descriptive statistics is provided in Table 1.

Table 1. Profile of Respondents

\begin{tabular}{llcc}
\hline Demographic characteristics & Frequency $(\mathrm{N}=399)$ & Percentage $(\%)$ \\
\hline Gender & Male & 230 & 57.6 \\
& Female & 169 & 42.4 \\
\hline Ethnicity & Malay & 77 & 19.3 \\
& Chinese & 257 & 64.4 \\
& Indian & 63 & 15.8 \\
& Others & 2 & 0.5 \\
\hline Age group & 21 to 29 & 195 & 48.9 \\
& 30 to 39 & 137 & 34.3 \\
& 40 to 49 & 56 & 14.0 \\
& 50 to 59 & 11 & 2.8 \\
\hline Education level & SPM & 84 & 21.1 \\
& Diploma & 239 & 59.9 \\
& Bachelor's degree & 63 & 15.8 \\
& Master's degree & 12 & 3.0 \\
& PhD degree & 1 & 0.3 \\
\hline Employment sector & Government & 15 & 3.8 \\
& Private & 311 & 77.9 \\
& Self-employed & 58 & 14.5 \\
& Pensioner & 1 & 0.3 \\
& Unemployed & 14 & 3.5 \\
\hline Investing experience & Less than 1 year & 43 & 10.8 \\
& 1 to 3 years & 222 & 55.6 \\
& 4 to 9 years & 122 & 30.6 \\
& 10 years or more & 12 & 3.0 \\
\hline
\end{tabular}

\subsection{Financial Statement Usage Among Individual Investors}

The following table shows the financial statement usage of Malaysian individual investors for investment decision-making. As can be seen, the income statement is the most commonly used followed by the cash flow statement and the income statement.

Table 2. Individual Investors' Financial statement usage for Investment Decision-Making

\begin{tabular}{lccccc}
\hline Type of Financial Statement & Mean & Median & SD & Min. & Max. \\
\hline Income statement & 4.11 & 4.00 & 1.41 & 1 & 7 \\
Balance sheet & 3.77 & 4.00 & 1.38 & 1 & 7 \\
Cash flow statement & 3.95 & 4.00 & 1.55 & 1 & 7 \\
\hline
\end{tabular}

Table 3 summarises the significance of the demographic differences for financial statement usage based on the t-test for gender and ANOVA for the other five demographic variables. 
Table 3. Significance of Demographic Differences for Financial Statement Usage

\begin{tabular}{lc}
\hline Demographic Factor & $p$ value \\
\hline Gender & 0.001 \\
Ethnicity & 0.188 \\
Age group & 0.000 \\
Education level & 0.003 \\
Employment sector & 0.004 \\
Investing experience & 0.000 \\
\hline
\end{tabular}

Females exhibited a higher level of financial statement usage compared to males. Interestingly, there were no significant differences in terms of ethnicity, suggesting that the various races have an equal likelihood of using financial statements for investment decision-making purposes. Financial statement usage also seemed to decline with age; respondents in their 20s reported a higher usage of financial statements compared to those in their 50s. Those who had a diploma had significantly higher financial statement usage compared to those with SPM qualifications; however, usage did not increase significantly with even higher educational attainment. Nonetheless, the findings support human capital theory that education is a driver of financial behaviour. Significant differences were also noted for the employment sector where those in the private sector exhibited higher usage compared to those who were unemployed. Furthermore, investors with 3 years or less investing experience were significantly higher users of financial statements compared to more experienced investors.

\subsection{Descriptive Statistics}

Table 4 depicts the means, standard deviations, and correlations among the variables studied.

Table 4. Means, Standard Deviations, and Correlations among Variables

\begin{tabular}{lllllllll}
\hline & Mean & SD & TotFSK & Tot $F$ & TotU & TotS & TotPCB & TotB \\
\hline TotFSK & 4.84 & 1.90 & 1.00 & & & & & \\
TotF & 13.25 & 3.36 & 0.02 & 1.00 & & & & \\
TotU & 13.79 & 3.20 & $0.27^{* *}$ & 0.02 & 1.00 & & & \\
TotS & 17.17 & 4.68 & $0.25^{* *}$ & $0.14^{* *}$ & $0.39^{* *}$ & 1.00 & & \\
TotPCB & 17.23 & 4.43 & $0.34^{* *}$ & $0.10^{*}$ & $0.58^{* *}$ & $0.61^{* *}$ & 1.00 & \\
TotB & 11.82 & 3.89 & $0.53^{* *}$ & -0.01 & $0.60^{* *}$ & $0.65^{* *}$ & $0.69^{* *}$ & 1.00 \\
\hline Notes: & ${ }^{* *} \mathrm{p}<0.01,{ }^{*} \mathrm{p}<0.05$ & & & & & &
\end{tabular}

The correlation coefficients revealed significant positive relationships between the dependent variable and financial statement knowledge, financial statement usage attitude, subjective norm, and perceived behavioural control. However, there was a negative correlation 
between trading frequency attitude and financial statement usage for investment decision-making.

\subsection{Multiple Regression Analysis}

Table 5. Results of Multiple Regression Analysis

\begin{tabular}{lccccc}
\hline & $\begin{array}{c}\text { Unstandardised } \\
\text { Coefficient }(\mathrm{B})\end{array}$ & $\begin{array}{c}\text { Standardised } \\
\text { Coefficient }(\beta)\end{array}$ & T statistic & $p$ & \\
\hline TotFSK & 0.606 & 0.296 & 9.964 & 0.000 & \\
TotF & -1.09 & -0.089 & -3.181 & 0.002 & \\
Tot $U$ & 0.291 & 0.252 & 7.312 & 0.000 & \\
Tot $S$ & 0.288 & 0.347 & 9.829 & 0.000 & \\
TotPCB & 0.208 & 0.236 & 5.845 & 0.000 & 0.696 \\
\hline $\mathrm{R}^{2}$ & & & & & 0.692 \\
Adj. $\mathrm{R}^{2}$ & & & & & $179.550^{* * *}$ \\
F & & & & & \\
\hline
\end{tabular}

Notes: $\quad{ }^{* * *} \mathrm{p}<0.0005$ (2-tailed)

Before performing multiple regression analysis, multicollinearity was assessed by examining the tolerance and variance inflation factor (VIF) of the independent variables. There was an absence of multicollinearity as the tolerance of each variable was more than 0.10 and the VIF was less than 10. The results of the multiple regression analysis are presented in Table 5. The model has an adjusted $\mathrm{R}^{2}$ of 0.692 , which indicates that it explains 69.2 per cent of the variance in financial statement usage among individual investors.

Of the five independent variables, subjective norm displayed the highest positive coefficient with individual investors' financial statement usage for investment decision-making, followed by financial statement knowledge, usage attitude, and perceived behavioural control. Trading frequency attitude was negatively associated with the dependent variable. The associations between each of the five independent variables and the dependent variable were significant at the 1 per cent level. Therefore, all five hypotheses were supported.

\subsection{Discussion}

The findings demonstrate that the level of financial statement usage among Malaysian individual investors is moderate and not as high as suggested in previous quantitative studies (Jamal et al., 2014; Lai et al., 2001, Nik Muhammad \& Abdullah, 2009). They also suggest that Malaysian individual investors are generally less reliant on financial statement usage than their counterparts in other countries (Al-Ajmi, 2009; De Zoysa \& Rudkin, 2010; Johansen \& Plenborg, 2013). 
Furthermore, compared to individual investors in other Asian countries (Al-Ajmi, 2009; De Zoysa \& Rudkin, 2010), Malaysian individual investors are less reliant on the balance sheet, which is unfortunate since this type of financial statement contains important value relevant information (Francis \& Schipper, 1999; Graham \& Dodd, 2009).

Regarding the factors that influence individual investors' financial statement usage, the findings supported all our hypotheses. The positive association between financial statement knowledge and the dependent variable supports human capital theory in which financial statement knowledge is regarded as a type of human capital that contributes to positive financial behaviour; namely, individual investors' financial statement usage for investment decision-making. This indicates that investors with high financial statement knowledge are more likely to use financial statements for investment decision-making.

However, surprisingly, subjective norm proved to be the strongest predictor variable, thus demonstrating the profound influence that family and friends exert on Malaysian individual investors' financial statement usage. The positive relationship between financial statement usage attitude and the dependent variable is consistent with the literature on $\mathrm{TPB}$, in which attitude towards a type of behaviour is a predictor of the behaviour itself. When individual investors have a positive attitude towards the benefits and usefulness of financial statements, they are more likely to use them for investment decisionmaking. Similarly, the association between perceived behavioural control and individual investors' financial statement usage is also consistent with the TPB literature. Individuals who perceive that they are able to understand and use financial statements are more likely to use financial statements for investment decision-making than those who display lower self-confidence in this regard.

As hypothesised, there was a negative association between trading frequency attitude and the dependent variable. This can be attributed to the nature of stock trading, which is influenced by short-term price fluctuations (Israelov \& Katz, 2011) rather than by the firm's annual financial performance. Hence, investors who trade more frequently are less reliant on financial statement usage.

What influences individual investors to use financial statements for investment decision-making is a largely unexplored subject. However, it is profoundly important in financial reporting to obtain a better understanding of individual investors' decision-making behaviour regarding financial statement usage since they represent a primary audience for which financial statements are prepared. Therefore, 
identifying and providing empirical evidence of the significance of knowledge and attitudinal factors influencing individual investors' financial statement usage represents the primary contribution of this study. In addition, we enrich the literature on financial statement usage among individual investors in Malaysia by showing the extent to which the three main financial statements are utilised by them. Apart from that, this research extends financial literacy research on stock investing to the realm of financial statement usage by highlighting the influence of financial statement knowledge on this behaviour since financial statement knowledge is essential in understanding financial statements. In doing so, we hope to bridge the gap between financial reporting and financial literacy.

We believe that this study provides useful insights for the providers of investor education programmes, such as those conducted by Bursa Malaysia and stock brokerage firms. While the effectiveness of these programmes has not been subject to study, research in other countries shows that, in general, financial education or literacy programmes tend to have short-lived effects on the participants (Poon \& Olen, 2015; Worthington, 2013). Our findings indicate that there is room for improvement regarding individual investors' financial statement knowledge and usage. Furthermore, we find that attitudes are highly significant in influencing individual investors' financial statement usage. This is not merely confined to a positive attitude regarding financial statement usage but a negative attitude towards overtrading and selfconfidence that the investor is able to understand and use financial statements for investment decision-making. Therefore, investor education programmes should be formulated to not only increase knowledge but also to shape positive attitudes. In light of the significant influence of the subjective norm on individual investors' financial statement usage, we believe that by educating some investors of the merits of financial statement usage, in turn, these investors will influence their social circles of these merits, thus creating a virtuous cycle of positive stock investing behaviour.

\section{Conclusion}

We examined the influence of financial statement knowledge and attitudinal factors on Malaysian individual investors' financial statement usage. We find that financial statement usage is positively associated with subjective norm, financial statement knowledge, attitude towards financial statement usage, and perceived behavioural control. However, it is negatively associated with trading frequency attitude. This study is 
intended to address the lack of studies on what motivates individuals to use financial statements for investment decision-making. A limitation of this research is that non-random sampling was employed, albeit such an approach is consistent with the literature. Another limitation is that we focused on individual investors who are proficient in English because we seek to complement Malaysian studies on the readability of English language financial statement narratives. Notwithstanding these shortcomings, we believe that this study provides insights into individual investor behaviour vis-à-vis financial statement usage that contributes to two streams of literature; namely, on financial reporting and financial literacy. In addition, the findings of the study can be used for developing more effective investor education programmes.

\section{References}

Abarbanell, J. S., \& Bushee, B. J. (1998). Abrnomal returns to a fundamental analysis strategy. The Accounting Review, 73(1), 19-45.

Abdul Raman, S., Mohd Shaari, S. N., \& Mahmud, N. M. (2012). A longitudinal study of the readability of the chairman's narratives in corporate reports: Malaysian evidence. International Journal of Social, Education, Economics and Management Engineering, 8(7), 2011-2018.

Abreu, M., \& Mendes, V. (2010). Financial literacy and portfolio diversification. Quantitative Finance, 10(5), 1-38.

ACCA (2012). Re-assessing the value of corporate reporting. London, United Kingdom: ACCA.

Agarwalla, S. K., Barua, S. K., Jacob, J., \& Varma, J. R. (2013). Financial literacy among working young in urban India. Ahmedabad, India: Indian Institute of Management Ahmedabad.

Ajzen, I. (1991). The theory of planned behavior. Organizational Behavior and Human Decision Processes, 50, 179-211.

Ajzen, I. (2006). Constructing a TpB questionnaire: Conceptual and methodological considerations. Retrieved from http://www.uni-bielefeld.de/

Ajzen, I. (2011). Constructing a theory of planned behaviour questionnaire. Retrieved from http:// people.umass.edu/

Ajzen, I., Joyce, N., Sheikh, S., \& Cote, N. G. (2011). Knowledge and the prediction of behavior: The role of information accuracy in the theory of planned behavior. Basic and Applied Social Psychology, 33, 101-117.

Al-Ajmi, J. (2009). Investors' use of corporate reports in Bahrain. Managerial Auditing Journal, 24(3), 266-289.

Alessie, R., van Rooij, M., \& Lusardi, A. (2011). Financial literacy and retirement preparation in the Netherlands. Journal of Pension Economics and Finance, 10(4), 527-545.

Ali, A., Rahman, M. S. A., \& Bakar, A. (2015). Financial satisfaction and the influence of financial literacy in Malaysia. Social Indicators Research, 120(1), 137-156. 
Arora, S., \& Marwaha, K. (2013). Financial literacy level and awareness regarding stock market. An empirical study of individual stock investors of Punjab. Management and Labour Studies, 38(3), 241-253.

Aruna, P. (2017, May 3). More young investors entering into Malaysian market. The Star. Retrieved from https://www.thestar.com.my/

Asaad, C. T. (2015). Financial literacy and financial behavior: Assessing knowledge and confidence. Financial Services Review, 24(2), 101-117.

Atkinson, A., \& Messy, F. A. (2012). Measuring financial literacy: Results of the OECD/International Network on Financial Education (INFE) pilot study. OECD Working Papers on Finance, Insurance and Private Pensions No. 15, 1-73.

Babiarz, P., \& Robb, C. A. (2014). Financial literacy and emergency saving. Journal of Family and Economic Issues, 35(1), 40-50.

Barber, B. M., Lee, Y.-T., Liu, Y.-J., \& Odean, T. (2009). Just how much do individual investors lose by trading? The Review of Financial Studies, 22(2), 609-632.

Barber, B. M., \& Odean, T. (2000). Trading is hazardous to your wealth: The common stock investment performance of individual investors. The Journal of Finance, 55(2), 773-806.

Barber, B. M., \& Odean, T. (2008). All that glitters: The effect of attention and news on the buying behavior of individual and institutional investors. The Review of Financial Studies, 21(2), 785-818.

Barber, B. M., \& Odean, T. (2013). The behavior of individual investors. In G. M. Constantinides, M. Harris \& R. M. Stulz (Eds.), Handbook of the Economics of Finance (p. 1533-1570). Amsterdam: Elsevier B.V.

Beattie, V., Dhanani, A., \& Jones, M. J. (2008). Investigating presentational changes in U.K. annual reports: A longitudinal perspective. Journal of Business Communication, 45(2), 181-222.

Behrman, J. R., Mitchell, O. S., Soo, C. K., \& Bravo, D. (2012). How financial literacy affects household wealth accumulation. The American Economic Review, 102(3), 300-304.

Ben-David, I., \& Hirshleifer, D. (2012). Are investors really reluctant to realize their losses? Trading responses to past returns and the disposition effect. The Review of Financial Studies, 25(8), 2485-2532.

Brennan, N. M., Pierce, A., \& Guillamon-Saorin, E. (2009). Impression management. Accounting, Auditing and Accountability Journal, 22(5), 789-832.

Brimble, M., \& Hodgson, A. (2007). On the intertemporal value relevance of conventional financial accounting in Australia. Accounting and Finance, 47, 599-622.

Bursa Malaysia. (2016). Opening of CDS account. Retrieved from http://customer.bursamalaysia.com/

Callen, J. L., Lai, K. M. Y., \& Wei, S. X. (2016). The volatility of return revisions and financial statement literacy in emerging markets: The case of crosslisted Chinese firms. Journal of Business Finance and Accounting, 43(5 \& 6), 572-596. 
Carpenter, T. D., \& Reimers, J. L. (2005). Unethical and fraudulent financial reporting: Applying the theory of planned behavior. Journal of Business Ethics, 60(2), 115-129.

Chen, P., \& Zhang, G. (2007). How do accounting variables explain stock price movements? Theory and evidence. Journal of Accounting and Economics, 43, 219-244.

Chung, Y., \& Park, Y. (2014). The effects of financial education and networks on business students' financial literacy. American Journal of Business Education, $7(3), 229-236$.

Clark, R., Lusardi, A., \& Mitchell, O. S. (2014). Financial knowledge and 401(k) investment performance. GFLEC Working Paper Series No. 2014-1, 1-27.

Companies Act 2016 (2016). Malaysian Law. Retrieved from http://www.agc.gov.my/

Creswell, J. W. (2014). Research design (4th ed.). Singapore: SAGE Publications Inc.

De Zoysa, A., \& Rudkin, K. (2010). An investigation of perceptions of company annual report users in Sri Lanka. International Journal of Emerging Markets, 5(2), 183-202.

Delavande, A., Rohwedder, S., \& Willis, R. (2008). Preparation for retirement, financial literacy and cognitive resources University of Michigan Retirement Center Working Paper No. 2008-190, 1-47.

Dennis, B. S., Buchholtz, A. K., \& Butts, M. M. (2009). The nature of giving. A theory of planned behavior examination of corporate philanthropy. Business and Society, 48(3), 360-384.

Dontoh, A., Radhakrishnan, S., \& Ronen, J. (2004). The declining value-relevance of accounting information and non-information-based trading: An empirical analysis. Contemporary Accounting Research, 21(4), 795-812.

Drake, M. S., Roulstone, D. T., \& Thornock, J. R. (2016). The usefulness of historical accounting reports. Journal of Accounting and Economics, 61, 448464.

Fowler, F. J. (2009). Survey research methods (4th ed.). Thousand Oaks, CA: Sage.

Francis, J., \& Schipper, K. (1999). Have financial statements lost their relevance? Journal of Accounting Research, 37(2), 319-352.

Gopi, M., \& Ramayah, T. (2007). Applicability of theory of planned behavior in predicting intention to trade online. International Journal of Emerging Markets, 2(4), 348-360.

Graham, B., \& Dodd, D. (2009). Security analysis (6th ed.). New York, NY: McGraw-Hill.

Graham, B., \& Zweig, J. (2006). The intelligent investor. New York, NY: Harper.

Graham, J. R., Harvey, C. R., \& Huang, H. (2009). Investor competence, trading frequency, and home bias. Management Science, 55(7), 1094-1106.

Grinblatt, M., \& Keloharju, M. (2009). Sensation seeking, overconfidence, and trading activity. The Journal of Finance, 64(2), 549-578.

Helppie, B., Kapinos, K. A., \& Willis, R. J. (2010). Occupational learning, financial knowledge, and the accumulation of retirement wealth. University of Michigan Retirement Research Center Working Paper No. 2010-237, 1-39. 
What Are the Factors That Influence Their Financial Statement Usage?

Hermanus, B. (2015, April 1). Analysis: Comparing RI financial market with other ASEAN countries The Jakarta Post. Retrieved from http://www.thejakartapost.com/

Howlett, E., Kees, J., \& Kemp, E. (2008). The role of self-regulation, future orientation, and financial knowledge in long-term financial decisions. The Journal of Consumer Affairs, 42(2), 223-242.

Hrasky, S., Mason, C., \& Wills, D. (2009). The textual complexity of annual report narratives: A comparison of high- and low-performance companies. New Zealand Journal of Applied Business Research, 7(2), 31-45.

Hung, A. A., Parker, A. M., \& Yoong, J. K. (2009). Defining and measuring financial literacy. RAND Labor and Population Working Papers, WR-708, 1-26.

Huston, S. J. (2010). Measuring financial literacy. The Journal of Consumer Affairs, 44(2), 296-316.

Ibrahim, D., Harun, R., \& Isa, Z. M. (2009). A study on financial literacy of Malaysian degree students. Cross-cultural Communication, 5(4), 51-59.

Israelov, R., \& Katz, M. (2011). To trade or not to trade? Informed trading with short-term signals for long-term investors. Financial Analysts Journal, 67(5), 23-36.

Jaiyeoba, H. B., \& Haron, R. (2016). A qualitative inquiry into the investment decision behaviour of the Malaysian stock market investors. Qualitative Research in Financial Markets, 8(3), 246-267.

Jamal, A. A. A., Ramlan, W. K., Pazim, K. H., \& Budin, D. S. A. (2014). Decisionmaking style and investment success of retail investors in Malaysia. International Journal of Business and Social Science, 5(1), 311-322.

Jappelli, T., \& Padula, M. (2011). Investment in financial literacy and savings decisions.CFS Working Paper No. 2011/07, 1-41.

Johansen, T. R., \& Plenborg, T. (2013). Prioritising disclosures in the annual report. Accounting and Business Research, 43(6), 605-635.

Jones, M. J., \& Shoemaker, P. A. (1994). Accounting narratives: A review of empirical studies of content and readability. Journal of Accounting Literature, $13,142$.

Khan, M. T. I., Tan, S.-H., \& Chong, L.-L. (2016). Gender differences in preferences for firm characteristics across different groups of investors. Qualitative Research in Financial Markets, 8(1), 2-15.

Klapper, L., Lusardi, A., \& van Oudheusden, P. (2015). Financial literacy around the world: Insights from the Standard and Poor's ratings services global financial literacy survey. Retrieved from http://gflec.org/

KPMG (2011). Disclosure overload and complexity: Hidden in plain sight. Retrieved from https:/ /www.kpmg.com/

Kumar, A. (2009). Hard-to-value stocks, behavioral biases, and informed trading. The Journal of Financial and Quantitative Analysis, 44(6), 1375-1401.

Lai, M.-M., Low, K. L. T., \& Lai, M.-L. (2001). Are Malaysian investors rational? Journal of Psychology and Financial Markets, 2(4), 210-215.

Lai, M.-M., Tan, S.-H., \& Chong, L.-L. (2013). The behavior of institutional and retail investors in Bursa Malaysia during the bulls and bears. Journal of Behavioral Finance, 14(2), 104-115. 
Landerretche, O. M., \& Martinez, C. (2013). Voluntary savings, financial behavior, and pension finance literacy: Evidence from Chile. Journal of Pension Economics and Finance, 12(3), 251-297.

Lease, R. C., Lewellen, W. G., \& Schlarbaum, G. G. (1974). The individual investor: Attributes and attitudes. The Journal of Finance, 29(2), 413-433.

Libby, R. (1975). The use of simulated decision makers in information evaluation. The Accounting Review, 50(2), 475-489.

Libby, R., Bloomfield, R., \& Nelson, M. W. (2002). Experimental research in financial accounting. Accounting, Organizations and Society, 27, 775-810.

Linnainmaa, J. T. (2011). Why so (some) households trade so much? The Review of Financial Studies, 24(5), 1630-1666.

Loke, Y. J. (2015). Financial knowledge and behaviour of working adults in Malaysia. Margin - The Journal of Applied Economic Research, 9(1), 18-38.

Loughran, T., \& McDonald, B. (2014). Regulation and financial disclosure: The impact of plain English. Journal of Regulatory Economics, 45(1), 94-113.

Lusardi, A., \& Mitchell, O. S. (2011). Financial literacy around the world: an overview. NBER Working Papers Series No. 17107, 1-17.

Lusardi, A., \& Mitchell, O. S. (2014). The economic importance of financial literacy: Theory and evidence. Journal of Economic Literature, 52(1), 5-44.

Lusardi, A., Mitchell, O. S., \& Curto, V. (2014). Financial literacy and financial sophistication in the older population. Journal of Pension Economics and Finance, 13(4), 347-366.

Malaysian Accounting Standards Board. (2011). The conceptual framework for financial reporting. Kuala Lumpur, Malaysia: Malaysian Accounting Standards Board.

Miller, B. P. (2010). The effects of reporting complexity on small and large investor trading. The Accounting Review, 85(6), 2107-2143.

Ministry of Education Malaysia. (2016). Quick facts 2016.Malaysia educational statistics. Putrajaya, Malaysia: Ministry of Education Malaysia.

Mohammad, R. \& Abdul Rhaman, A. (2006). Readability of corporate annual reports of top 100 Malaysian companies. Malaysian Management Journal, $10(1 \& 2), 33-47$.

Monticone, C. (2010). How much does wealth matter in the acquisition of financial literacy? The Journal of Consumer Affairs, 44(2), 403-422.

Moser, A. K. (2015). Thinking green, buying green? Drivers of pro-environmental purchasing behavior. Journal of Consumer Marketing, 32(3), 167-175.

Mouna, A., \& Jarboui, A. (2015). Financial literacy and portfolio diversification: An observation from the Tunisian stock market. International Journal of Bank Marketing, 33(6), 808-822.

Nagy, R. A., \& Obenberger, R. W. (1994). Factors influencing individual investor behavior. Financial Analysts Journal, 50(4), 63-68.

Nik Muhammad, N. M., \& Abdullah, M. (2009). Investment decision making style: Are Malaysian investors rational decision makers? Interdisciplinary Journal of Contemporary Research in Business, 1(3), 96-108.

Organisation for Economic Co-operation and Development (OECD) International Network on Financial Education (INFE) (2016). OECD/INFE 
International survey of adult financial literacy competencies. Paris, France: OECD/INFE.

Pascual-Ezama, D., Scandroglio, B., \& Liaño, B. G.G. D. (2013). Can we predict individual investors' behavior in stock markets? A psychological approach. Universitas Psychologica, 13(1), 25-35.

Phan, K. C., \& Zhou, J. (2014). Factors influencing individual investor behavior: An empirical study of the Vietnamese stock market. American Journal of Business and Management, 3(2), 77-94.

Piotroski, J. D. (2000). Value investing: The use of historical financial statement information to separate winners from losers. Journal of Accounting Research, 38(Sup), 1-41.

Poon, M., \& Olen, H. (2015). Does literacy improve finance? Public Understanding of Science, 24(3), 272-284.

Psacharopoulos, G. (2006). The value of investing in education: Theory, evidence and policy. Journal of Education Finance, 32(2), 113-136.

Ramayah, T., Mohd. Yusoff, Y., Jamaludin, N., \& Ibrahim, A. (2009). Applying the theory of planned behavior (TPB) to predict internet tax filing intentions. International Journal of Management, 26(2), 272-284.

Richardson, S., Sloan, R., \& You, H. (2012). What makes stock prices move? Fundamentals vs. investor recognition. Financial Analysts Journal, 68(2), 3050.

Robb, C. A. (2011). Financial knowledge and credit card behavior of college students. Journal of Family and Economic Issues, 32(4), 690-698.

Robb, C. A., \& Woodyard, A. S. (2011). Financial knowledge and best practice behavior. Journal of Financial Counseling and Planning, 22(1), 60-70.

Sabri, M. F., \& MacDonald, M. (2010). Savings behavior and financial problems among college students: The role of financial literacy in Malaysia. Crosscultural Communication, 6(3), 103-110.

Sondari, M. C., \& Sudarsono, R. (2015). Using theory of planned behavior in predicting intention to invest: Case of Indonesia. International Academic Research Journal, 1(2), 137-141.

Spataro, L., \& Corsini, L. (2013). Endogenous financial literacy, saving and stock market participation. MPRA Paper No. 44342, 1-20.

Stanton, P., \& Stanton, J. (2002). Corporate annual reports: Research perspectives used. Accounting, Auditing and Accountability Journal, 15(4), 478-500.

Statman, M., Thorley, S., \& Vorkink, K. (2006). Investor overconfidence and trading volume. The Review of Financial Studies, 19(4), 1531-1565.

Tan, H. B., Hoe, S. Y., \& Hung, W. T. (2011). Financial literacy and personal financial planning in Klang Valley, Malaysia. International Journal of Economics and Management, 5(1), 149-168.

van Rooij, M., Lusardi, A., \& Alessie, J. M. R. (2007). Financial literacy and stock market participation. CFS Working Paper No. 2007/27, 1-46.

Wang, A. (2009). Interplay of investors' financial knowledge and risk taking. Journal of Behavioral Finance, 10(4), 204-213.

Warner, H. W., \& Aberg, L. (2006). Drivers' decision to speed: A study inspired by the theory of planned behavior. Transportation Research (Part F9), 427-433. 
Wood, R., \& Zaichkowsky, J. L. (2004). Attitudes and trading behavior of stock market investors: A segmentation approach. Journal of Behavioral Finance, 5(3), 170-179.

Worthington, A. C. (2013). Financial literacy and financial literacy programmes in Australia. Journal of Financial Services Marketing, 18(3), 227-240.

Xia, T., Wang, Z., \& Li, K. (2014). Financial literacy overconfidence and stock market participation. Social Indicators Research, 119, 1233-1245.

$\mathrm{Xu}, \mathrm{L} .$, \& Zia, B. (2012). Financial literacy around the world: an overview of the evidence with practical suggestions for the way forward. Washington, DC: The World Bank.

Yao, R., \& Xu, Y. (2015). Chinese urban households' security market participation: Does investment knowledge and having a long-term plan help? Journal of Family and Economic Issues, 36, 328-339.

Yeoh, K. (2010). The behaviour of individual investors in Malaysia: A governance perspective. Doctoral thesis, Northumbria University, Northumbria, United Kingdom. Retrieved from http://nrl.northumbria.ac.uk/ 